\title{
Cryptococcus cyanovorans sp. nov., a basidiomycetous yeast isolated from cyanide-contaminated soil
}

\author{
Thabiso E. Motaung, Jacobus Albertyn, Johan L. F. Kock \\ and Carolina H. Pohl
}

Correspondence

Carolina H. Pohl

PohICH@ufs.ac.za

\author{
Department of Microbial, Biochemical, and Food Biotechnology, University of the Free State, \\ PO Box 339, Bloemfontein 9300, South Africa
}

\begin{abstract}
Eighteen yeast strains were isolated and identified from cyanide-contaminated soil in South Africa. According to sequence-based analyses using the D1/D2 region of the large ribosomal subunit and ITS region, three of these strains were found to be identical and represent a novel species. Phylogenetic analysis based on the combined dataset of the D1/D2 and ITS regions revealed a grouping with Cryptococcus curvatus, representing a defined clade (Curvatus) in the order Trichosporonales. The three strains were demarcated from Cryptococcus curvatus by standard physiological tests such as assimilation of lactose, xylitol, 5-keto-D-gluconate, succinate and citrate as well as growth on media containing $10 \%(\mathrm{w} / \mathrm{v}) \mathrm{NaCl}$ and $5 \%(\mathrm{w} / \mathrm{v})$ glucose. In addition, it was established that these strains could utilize up to $10 \mathrm{mM} \mathrm{NaCN}$ as sole carbon source on solid media and as sole nitrogen source in liquid media. On the basis of these findings, it is suggested that the three strains represent a novel species for which the name Cryptococcus cyanovorans sp. nov. is given (type strain CBS $11948^{\top}=N R R L Y-48730^{\top}$ ).
\end{abstract}

Isolation of yeasts from industrial wastewaters and related habitats, such as contaminated soils, has become the subject of research due to the economic and public impacts that arise from these sites (Boening \& Chew, 1999; Kjeldsen, 1999). Industrial processes such as gold and silver extraction through cyanidation contribute to the production of a number of toxic cyanide compounds that affect living organisms, causing serious environmental and health concerns (Atkinson et al., 1998; Rachinger et al., 2002; Pham et al., 2007). Previous efforts to combat contamination by cyanides were based on the use of chemicals such as ferrous sulphate (Adams, 1992). Currently, the use of micro-organisms to transform or mineralize toxic pollutants has gained prominence as a relevant substitute to reduce the toxicity of polluting cyanides (Boopathy, 2000).

Bioremediation of cyanides is mainly reported in studies focusing on the use of algae, filamentous fungi and bacteria (Dumestre et al., 1997; Barclay et al., 1998; Akcil, 2003; Ezzi \& Lynch, 2005; Gurbuz et al., 2009). Although studies have reported yeast strains that can bioremediate heavy metals, including chromium, copper, zinc and nickel [e.g.

The GenBank/EMBL/DDBJ accession numbers for the $26 \mathrm{~S}$ rDNA gene D1/D2 domain of strains CBS 11948', CBS 11949 and CBS 11950 are JF680899, JF680897 and JF680901, respectively. The GenBank/EMBL/DDBJ accession numbers for the internal transcribed spacer regions of strains CBS $11948^{\top}$, CBS 11949 and CBS 11950 are JF680900, JF680898 and JF680902, respectively.
Meyerozyma (Pichia) guilliermondii and Saccharomyces cerevisiae] (Machado et al., 2008) as well as organic cyanides such as benzonitrile (Cryptococcus sp. UFMSY-28) and phenylacetonitrile (e.g. Exophiala oligosperma) (Rezende et al., 2000; Rustler \& Stolz, 2007), only one strain, Cryptococcus humicola $\mathrm{MCN} 2$, is reported to biodegrade inorganic cyanide compounds (Kwon et al., 2002).

During the study of unidentified yeast isolates deposited in the UNESCO-MIRCEN Biotechnological Yeast Culture Collection housed at the Department of Microbial, Biochemical and Food Biotechnology of the University of the Free State, South Africa, a group of isolates obtained from cyanide-contaminated soil from Sasolburg, South Africa were identified. These strains were all isolated from the same site; however, they were obtained from different soil samples taken from the site. Three of these strains, each isolated from a different sample, were found to belong to a previously undescribed species in the genus Cryptococcus. The name Cryptococcus cyanovorans sp. nov. is proposed for this novel species.

Isolation of DNA was performed on yeast cells grown for approximately $24 \mathrm{~h}$ at $30{ }^{\circ} \mathrm{C}$ in yeast malt extract (YM) broth (per litre, $3 \mathrm{~g}$ yeast extract, $3 \mathrm{~g}$ malt extract, $5 \mathrm{~g}$ peptone and $10 \mathrm{~g}$ glucose). Isolation of DNA was achieved either by genomic DNA extraction (Labuschagne \& Albertyn, 2007) or by heating $\left(10 \mathrm{~min}\right.$ at $\left.96^{\circ} \mathrm{C}\right)$ cells from a single colony suspended in $20 \mu$ triple distilled water. PCR was performed for the 26S rDNA gene D1/D2 and ITS 
Table 1. Strains identified from cyanide-contaminated soil

UOFS, strains are maintained in the UNESCO-MIRCEN Biotechnology Yeast Culture Collection, University of the Free State.

\begin{tabular}{|ll|}
\hline Species & \multicolumn{1}{c|}{ Strains } \\
\hline $\begin{array}{l}\text { Ascomycetous yeasts } \\
\text { Candida rugosa }\end{array}$ & UOFS Y-2229 \\
Candida sorbophila & UOFS Y-2372 \\
Basidiomycetous yeasts & \\
Cryptococcus curvatus & UOFS Y-2254 \\
Cryptococcus curvatus & UOFS Y-2263 \\
Cryptococcus cyanovorans sp. nov. & CBS 11948 ${ }^{\mathrm{T}}\left(=\mathrm{NRRL} \mathrm{Y}-48730^{\mathrm{T}}\right)$ \\
Cryptococcus cyanovorans sp. nov. & CBS $11949(=\mathrm{NRRL} \mathrm{Y}-48728)$ \\
Cryptococcus cyanovorans sp. nov. & CBS $11950(=\mathrm{NRRL} \mathrm{Y}-48729)$ \\
Rhodosporidium toruloides & UOFS Y-2233 \\
Rhodosporidium toruloides & UOFS Y-2257 \\
Rhodosporidium toruloides & UOFS Y-2265 \\
Rhodosporidium toruloides & UOFS Y-2234 \\
Rhodosporidium toruloides & UOFS Y-2373 \\
Rhodosporidium toruloides & UOFS Y-2261 \\
Rhodosporidium toruloides & UOFS Y-2247 \\
Rhodosporidium toruloides & UOFS Y-2255 \\
Rhodosporidium toruloides & UOFS Y-2231 \\
Rhodosporidium toruloides & UOFS Y-2370 \\
Trichosporon montevideense & UOFS Y-2266 \\
& \\
\hline
\end{tabular}

regions using fungal primers NL-1 (5'-GCATATCAATAAGCGGAGGAAAAG-3') and NL-4 (5'-GGTCCGTGTTTCAAGACGG-3'), ITS-4 (5'-TCCTCCGCTTATTGATATGS-3') and ITS-5 (5'-GGAAGTAAAAGTCGTAACAAGG-3'), respectively (White et al., 1990; Kurtzman \& Robnett, 1998). Sequences for both the rDNA genes and ITS regions were obtained with the ABI BigDye Terminator Cycle sequencing kit (Applied Biosystems). Resulting sequences were analysed using Geneious Pro 4.8 (Drummond et al., 2009) and compared with sequences in GenBank using the BLAST search algorithm (http:// www.ncbi.nlm.nih.gov). Sequences were aligned using CLUSTAL_X version 2.0 (Larkin et al., 2007). Phylogenetic and molecular evolutionary analyses were conducted with MEGA version 4 (Tamura et al., 2007) using the neighbour-joining method with the Kimura two-parameter distance measure. Confidence values were estimated from bootstrap analysis of 1000 replicates.

Morphological and physiological properties of strains were determined according to standard methods (van der Walt \& Yarrow, 1984; Yarrow, 1998). Scanning electron microscopy (SEM) was conducted on 3-dayold cultures, incubated at $25{ }^{\circ} \mathrm{C}$ on YM agar. The cells were fixed according to van Wyk \& Wingfield (1994) and scanning electron micrographs were taken with a JEOL 6400 WIN-SEM. The ability of these novel strains, as well as other strains isolated from cyanide-contaminated soil and Cryptococcus curvatus CBS $570^{\mathrm{T}}$ and Cryptococcus humicolus CBS 2042, to grow in the presence of $\mathrm{NaCN}$ as sole nitrogen source in liquid media was assessed as follows. Cells from strains were starved by cultivation in yeast nitrogen base (YNB) without ammonium sulphate and amino acids (per litre $1.7 \mathrm{~g}$ YNB and $10 \mathrm{~g}$ glucose) following the procedure of Müller et al. (2007). After this period, cells were tested for nitrogen source assimilation using minimal medium (containing, per litre, $4.3 \mathrm{~g} \mathrm{~K}_{2} \mathrm{HPO}_{4}, 3.4 \mathrm{~g} \mathrm{KH}_{2} \mathrm{PO}_{4}$ and $0.3 \mathrm{~g} \mathrm{MgCl}_{2}$ ) containing $10 \mathrm{~g} \mathrm{l}^{-1}$ glucose and $10 \mathrm{mM}$ $\mathrm{NaCN}$. Cells were incubated for $120 \mathrm{~h}$ at $30{ }^{\circ} \mathrm{C}$. The ability of strains to assimilate $\mathrm{NaCN}$ as sole carbon source was assessed using complete YNB medium $\left(6.7 \mathrm{~g} \mathrm{l}^{-1}\right)$ containing $10 \mathrm{mM} \mathrm{NaCN}$ and incubated at $30{ }^{\circ} \mathrm{C}$ for 10 days.

Eighteen previously unidentified strains, isolated from cyanide-contaminated soil and held in the UNESCOMIRCEN Biotechnological Yeast Culture Collection, University of the Free State, South Africa, were identified during this study (Table 1). The ascomycetous yeasts identified were Candida rugosa and Candida sorbophila and the basidiomycetous yeasts identified were Cryptococcus curvatus, Rhodosporidium toruloides and Trichosporon montevideense. Three strains were found to represent a previously undescribed species in the genus Cryptococcus.

The basidiomycete genus Cryptococcus Vuillemin is polyphyletic and comprises more than 50 anamorphic species distributed in the class Tremellomycetes, orders Cystofilobasidiales, Filobasidiales, Tremellales and Trichosporonales (Fell et al., 2000; Scorzetti et al., 2002; Golubev et al., 2006; Boekhout et al., 2011). Because of the polyphyletic nature of species of the genus Cryptococcus, proper phylogenetic positioning is often difficult and requires comprehensive and thorough analyses of sequence data (Nakase et al., 1993; Fell et al., 2000). In addition, phylogenetic groups within orders such as the Trichosporonales are frequently redescribed based on the inclusion of previously unknown species that may represent unrecognized subgroups. The latter order is described in literature based on six subgroups, i.e. Cutaneum, Formosensis, Gracile/Brassicae, Humicola, Ovoides and Porosum (Takashima et al., 2001; Scorzetti et al., 2002; Middelhoven et al., 2004; Takashima et al., 2009; Pagnocca et al., 2010). The Humicola subgroup was reported to be the only group in the order Trichosporonales comprising only members of the genus Cryptococcus (i.e. C. humicola, C. longus, C. musci, C. ramirezgomezianus and $C$. pseudolongus) while other members of this genus in this lineage, such as Cryptococcus curvatus, Cryptococcus daszewskae and Cryptococcus fragicola, are poorly supported (Takashima et al., 2001; Okoli et al., 2007; Takashima et al., 2009). The current paper proposes the description of Cryptococcus cyanovorans sp. nov. (type strain CBS $11948^{\mathrm{T}}$, additional strains CBS 11949 and CBS 11950) which, together with the closely related species Cryptococcus curvatus, represent another subgroup (Curvatus), comprising only members of the genus Cryptococcus in the order Trichosporonales (Fig. 1). 


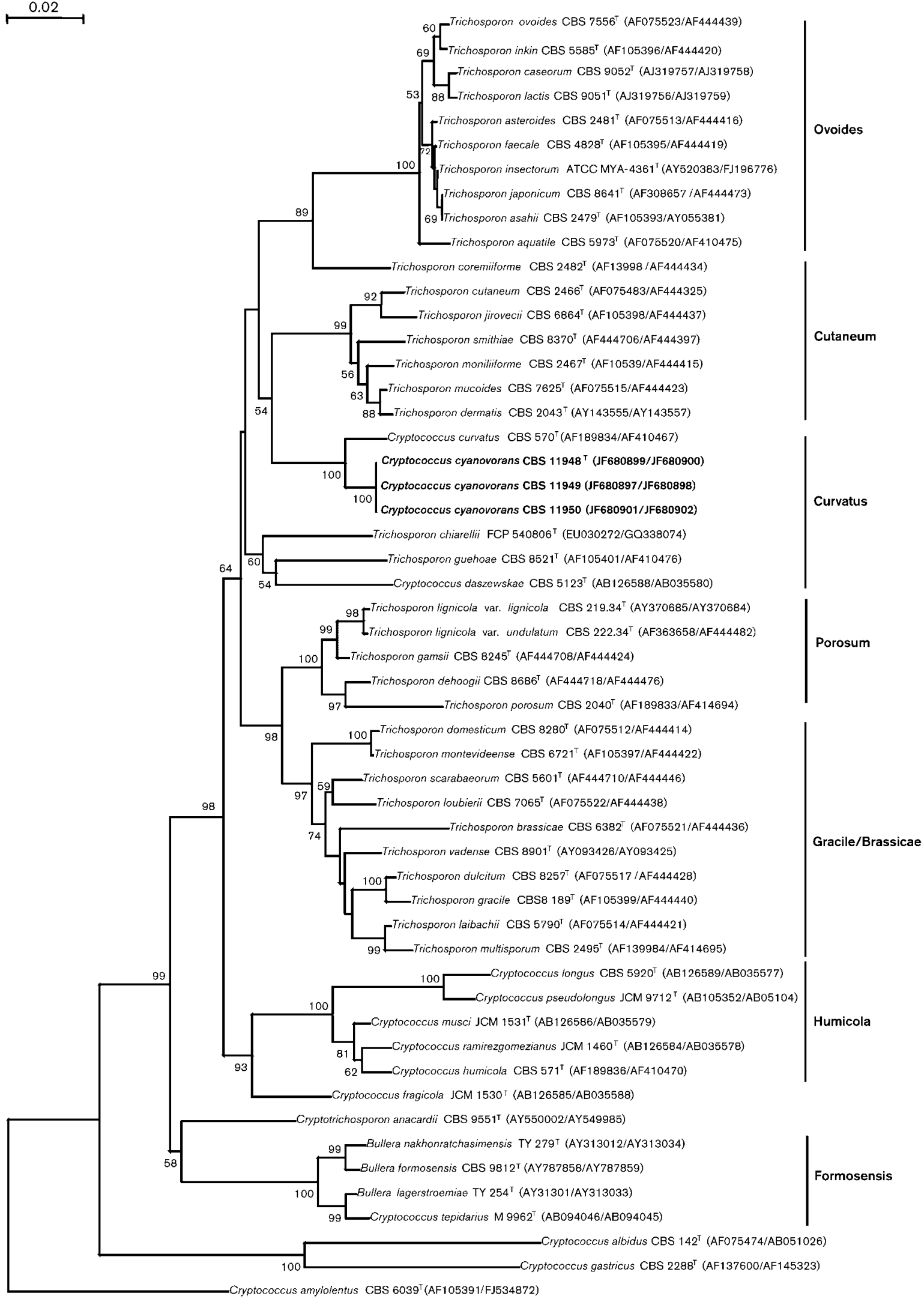


Fig. 1. Phylogenetic placement of Cryptococcus cyanovorans sp. nov. in the Curvatus subgroup using the neighbour-joining method with the Kimura two-parameter distance measure. Analysis was performed based on concatenated sequences of $26 \mathrm{~S}$ rDNA gene D1/D2 region and the ITS domain. Bootstrap percentage (1000 replicates) of $\geqslant 50 \%$ are shown. Bar, $2 \%$ nucleotide sequence divergence. Cryptococcus amylolentus was used as the outgroup species in the analysis. Sequences were retrieved from the GenBank/EMBL/DDBJ database using the accession numbers indicated on the tree.

Physiological and biochemical studies demonstrated that the three novel Cryptococcus strains conformed to the current description of this genus as observed by the utilization of D-glucuronate and myo-inositol as well as positive reactions for Diazonium Blue B salt and urease activity (Fell \& Statzell-Tallman, 1998; Fonseca et al., 2011). In addition, these strains were unable to ferment Dglucose. The strains demonstrated consistent differences in their abilities to assimilate certain carbon and nitrogen sources, to grow in the presence of $0.1 \%$ cycloheximide, to produce extracellular starch and to liquefy gelatin (Table 2). This, considered together with the fact that each of the strains was obtained from a different soil sample taken from the site, demonstrates the independence of the three strains. Growth studies on cyanide revealed that Cryptococcus cyanovorans sp. nov. was able to assimilate up to $10 \mathrm{mM} \mathrm{NaCN}$ as sole carbon and nitrogen source. This species is phenotypically distinct from Cryptococcus curvatus, as indicated in Table 3. The only other strain in this study that was able to assimilate cyanide, albeit to a lesser extent, was Rhodosporidium toruloides UOFS Y-2233.

Table 2. Phenotypic characteristics of the three different strains of Cryptococcus cyanovorans sp. nov.

+ , Positive; -, negative.

\begin{tabular}{|c|c|c|c|}
\hline Characteristic & $\begin{array}{c}\text { CBS } \\
11948^{\mathrm{T}}\end{array}$ & $\begin{array}{c}\text { CBS } \\
11949\end{array}$ & $\begin{array}{c}\text { CBS } \\
11950\end{array}$ \\
\hline \multicolumn{4}{|c|}{ Carbon source assimilation: } \\
\hline L-Arabinose & - & + & - \\
\hline Raffinose & + & - & + \\
\hline Erythritol & + & - & + \\
\hline Ribitol & + & + & - \\
\hline Glucitol & - & + & + \\
\hline Lactate & + & + & - \\
\hline Propane-1,2-diol & + & + & - \\
\hline Butane-2,3-diol & + & - & - \\
\hline \multicolumn{4}{|c|}{ Nitrogen source assimilation: } \\
\hline Nitrate & + & - & + \\
\hline Nitrite & + & - & + \\
\hline L-Lysine & + & + & - \\
\hline Cadaverine & + & - & + \\
\hline Creatinine & + & - & - \\
\hline Imidazole & + & - & + \\
\hline $\begin{array}{l}\text { Growth in } 0.01 \% \\
\text { cycloheximide }\end{array}$ & - & + & + \\
\hline Starch formation & + & - & + \\
\hline Gelatin liquefaction & - & + & - \\
\hline
\end{tabular}

\section{Latin diagnosis of Cryptococcus cyanovorans Motaung, Albertyn, J. L. F. Kock et Pohl sp. nov.}

In medio liquid extracto fermenti confecto post dies tres ad $25{ }^{\circ} \mathrm{C}$, cellulae globosae ad cylindricae $(1.2-7.2 \mu \mathrm{m} \times 1.2-$ $8.8 \mu \mathrm{m})$. Cellulae polariter gemmantes, circumglobatae et binae coherentes. In agaro extracto fermenti et extracto malti confecto, post dies tres ad $25{ }^{\circ} \mathrm{C}$, cultura glabra, cremea, margine integra aut fimbriata. In agaro Dalmau nec pseudohyphae nec hyphae formantur. Non fermentat. D-glucosum, D-galactosum, N-acetylglucosaminum, ribosum, xylosum, L-arabinosum (variabile), sucrosum, maltosum, $\alpha, \alpha$-trehalosum, methyl $\alpha$-glucosidum, cellobiosum, salicinum, arbutinum, raffinosum (variable), melezitosum, glycerolum, erythritolum (variabile), ribitolum (variabile), glucitolum (variabile), myo-inositolum, gluconatum, Dglucuronatum, lactatum (variabile), malatum, propan-1, 2-diolum (variabile), butan-2,3-diolum (variabile) et cyanidum assimulantur, neque sorbosum, rhamnosum, lactosum, inulinum, amylum solubile, xylitolum, arabitolum, mannitolum, dulcitolum, 2-keto D-gluconatum, 5-keto Dgluconatum, succinatum, citratum, ethanolum, methanolum, saccharatum, hexadecanum. Nitratum (variabile), nitritum (variabile), ethylaminum, L-lysinum (variabile), cadaverinum (variabile), imidazolum (variabile) et cyanidum assimulantur. Ureum finditur. Vitamina externa non necessaria. Materia amyloidea formatur (variabile). In medio $0.01 \%$ cycloheximidum crescit (variabile). Crescit in medio $1 \%$ aceticum acidum et $10 \% \mathrm{NaCl} / 5 \%$ glucosum neque in medio $50 \%$ glucosum contente. Gelatinum non liquescit. Crescit ad $37{ }^{\circ} \mathrm{C}$. Typus praeservatus in collectione zymotica Centraalbureau voor Schimmelcultures, Utrecht, Neerlandia (CBS $\left.11948^{\mathrm{T}}\right)$ et in collectione zymotica Agricultural Research Services United States Department of Agriculture, Peoria, Illinois (NRRL $\left.\mathrm{Y}-48730^{\mathrm{T}}\right)$.

Table 3. Distinguishing characteristics of Cryptococcus cyanovorans sp. nov. and the related species Cryptococcus curvatus (taken from Boekhout et al., 2011)

\begin{tabular}{|lcc|}
\hline Assimilation & C. cyanovorans & C. curvatus \\
\hline Carbon source & & \\
Lactose & - & + \\
Xylitol & - & + \\
5 -Keto D-gluconate & - & + \\
Succinate & - & + \\
Citrate & - & + \\
Additional tests & & - \\
$10 \% \mathrm{NaCl} / 5 \%$ D-Glucose & + & \\
\hline
\end{tabular}


Table 4. Assimilation of carbon and nitrogen sources by Cryptococcus cyanovorans sp. nov.

+ , Positive; -, negative; v, variable.

\begin{tabular}{|c|c|}
\hline Assimilation & Cryptococcus cyanovorans sp. nov. \\
\hline \multicolumn{2}{|l|}{ Carbon source } \\
\hline D-Glucose & + \\
\hline D-Galactose & + \\
\hline Sorbose & - \\
\hline$N$-Acetylglucosamine & + \\
\hline Ribose & + \\
\hline Xylose & + \\
\hline L-Arabinose & $\mathrm{V}$ \\
\hline Rhamnose & - \\
\hline Sucrose & + \\
\hline Maltose & + \\
\hline$\alpha, \alpha$-Trehalose & + \\
\hline Methyl $\alpha$-glucoside & + \\
\hline Cellobiose & + \\
\hline Salicin & + \\
\hline Arbutin & + \\
\hline Lactose & - \\
\hline Raffinose & $\mathrm{V}$ \\
\hline Melezitose & + \\
\hline Inulin & - \\
\hline Starch & - \\
\hline Glycerol & + \\
\hline Erythritol & $\mathrm{V}$ \\
\hline Ribitol & $\mathrm{V}$ \\
\hline Xylitol & - \\
\hline Arabitol & - \\
\hline Glucitol & $\mathrm{V}$ \\
\hline Mannitol & - \\
\hline Dulcitol & - \\
\hline myo-Inositol & + \\
\hline 2-Keto D-gluconate & - \\
\hline 5-Keto D-gluconate & - \\
\hline Gluconate & + \\
\hline D-Glucuronate & + \\
\hline Lactate & $\mathrm{V}$ \\
\hline Succinate & - \\
\hline Citrate & - \\
\hline Malate & + \\
\hline Ethanol & - \\
\hline Methanol & - \\
\hline Propane-1,2-diol & $\mathrm{v}$ \\
\hline Butane-2,3-diol & $\mathrm{V}$ \\
\hline Saccharate & - \\
\hline Hexadecane & - \\
\hline Cyanide & + \\
\hline \multicolumn{2}{|l|}{ Nitrogen source } \\
\hline Nitrate & $\mathrm{V}$ \\
\hline Nitrite & $\mathrm{V}$ \\
\hline Ethylamine & + \\
\hline L-Lysine & $\mathrm{V}$ \\
\hline Cadaverine & $\mathrm{V}$ \\
\hline Creatinine & $\mathrm{V}$ \\
\hline Imidazole & $\mathrm{V}$ \\
\hline Cyanide & + \\
\hline
\end{tabular}

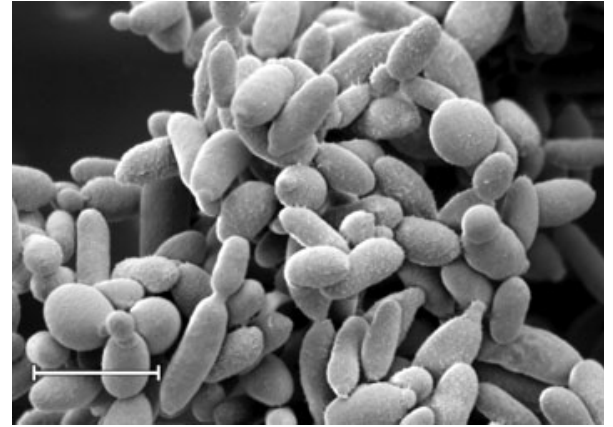

Fig. 2. Globose to elongate budding cells of Cryptococcus cyanovorans sp. nov. after 3 days at $25^{\circ} \mathrm{C}$ on YM agar. Bar, $5 \mu \mathrm{m}$.

\section{Description of Cryptococcus cyanovorans Motaung, Albertyn, J. L. F. Kock \& Pohl sp. nov.}

Cryptococcus cyanovorans (cy.a.no.vo' rans. N.L. adj. cyanovorans referring to the ability of this strain to assimilate cyanide).

In yeast extract peptone medium after 3 days at $25{ }^{\circ} \mathrm{C}$, cells are globose to elongate $(1.2-7.2 \mu \mathrm{m} \times 1.2-8.8 \mu \mathrm{m})$. Monoand bipolar budding is observed and cells occur in clusters or pairs (Fig. 2). In yeast malt extract (YM) agar after 3 days at $25{ }^{\circ} \mathrm{C}$, colonies are smooth, cream-coloured with entire or fringed margins. In Dalmau plate cultures on cornmeal agar, pseudo or true mycelia are not formed. No fermentation of carbon compounds is observed. The carbon and nitrogen source assimilation profiles are given in Table 4. Urea is hydrolysed and vitamins are not required for growth. Starch production and growth in the presence of $0.01 \%$ cycloheximide is variable. Growth is observed on $1 \%$ acetic acid and $10 \% \mathrm{NaCl}$ plus $5 \%$ glucose, but not on $50 \%$ glucose. Gelatin is not liquefied. Growth is observed at $37{ }^{\circ} \mathrm{C}$.

The type strain, CBS $11948^{\mathrm{T}}\left(=\mathrm{NRRL} \mathrm{Y}-48730^{\mathrm{T}}\right.$ ), as well as two additional strains, CBS 11949 (=NRRL Y-48728) and CBS 11950 (=NRRL Y-48729), are deposited in the yeast culture collection of the Centraalbureau voor Schimmelcultures, Utrecht, The Netherlands, with copies at the Agricultural Research Service Culture Collection, United States Department of Agriculture, Peoria, Illinois, USA.

\section{Acknowledgements}

The authors would like to acknowledge Mrs Andri van Wyk for providing the strains used in the study, Professor Peter van Wyk (Centre for Confocal and Electron Microscopy, University of the Free State, South Africa) for his assistance during microscopic experiments and Ms Keneuwe Selefo for conducting cyanide experiments. This work is based upon research supported by the National Research Foundation and Department of Science and Technology under the SABI Programme. Any opinion, findings and conclusions or recommendations expressed in this material are those of the authors and therefore the NRF and DST do not accept any liability in regard thereto. 


\section{References}

Adams, A. D. (1992). The removal of cyanide from aqueous solution by the use of ferrous sulphate. J S Afr Inst Min Metall 92, $17-26$.

Akcil, A. (2003). Destruction of cyanide in gold mill effluents: biological versus chemical treatments. Biotechnol Adv 21, 501-511.

Atkinson, B. W., Bux, F. \& Kasan, H. C. (1998). Considerations for application of biosorption technology to remediate metal-contaminated industrial effluents. Water SA 24, 129-136.

Barclay, M., Tett, V. A. \& Knowles, C. J. (1998). Metabolism and enzymology of cyanide/metallocyanide biodegradation by Fusarium solani under neutral and acidic conditions. Enzyme Microb Technol 23, 321-330.

Boekhout, T., Fonseca, Á., Sampaio, J. P., Bandoni, R. J., Fell, J. W. \& Kwon-Chung, K. J. (2011). Discussion of teleomorphic and anamorphic basidiomycetous yeasts. In The Yeasts, a Taxonomic Study, 5th edn, pp. 1339-1372. Edited by C. P. Kurtzman, J. W. Fell \& T. Boekhout. Amsterdam: Elsevier.

Boening, D. W. \& Chew, C. M. (1999). A critical review: general toxicity and environmental fate of three aqueous cyanide ions and associated ligands. Water Air Soil Pollut 109, 67-79.

Boopathy, R. (2000). Factors limiting bioremediation technologies. Bioresour Technol 74, 63-67.

Drummond, A. J., Ashton, B., Cheung, M., Heled, J., Kearse, M., Moir, R., Stones-Havas, S., Thierer, T. \& Wilson, A. (2009). Geneious v4.7, available from http://www.geneious.com

Dumestre, A., Chone, T., Portal, J., Gerard, M. \& Berthelin, J. (1997). Cyanide degradation under alkaline conditions by a strain of Fusarium solani isolated from contaminated soils. Appl Environ Microbiol 63, 2729-2734

Ezzi, M. I. \& Lynch, J. M. (2005). Biodegradation of cyanide by Trichoderma spp. and Fusarium spp. Enzyme Microb Technol 36, 849854.

Fell, J. W. \& Statzell-Tallman, A. (1998). Cryptococcus Vuillemin. In The Yeasts, a Taxonomic Study, 4th edn, pp. 742-767. Edited by C. P. Kurtzman \& J. W. Fell. Amsterdam: Elsevier.

Fell, J. W., Boekhout, T., Fonseca, Á., Scorzetti, G. \& StatzellTallman, A. (2000). Biodiversity and systematics of basidiomycetous yeasts as determined by large-subunit rDNA D1/D2 domain sequence analysis. Int J Syst Evol Microbiol 50, 1351-1371.

Fonseca, Á., Boekhout, T. \& Fell, J. W. (2011). Cryptococcus Vuillemin. In The Yeasts, a Taxonomic Study, 5th edn, pp. 16611737. Edited by C. P. Kurtzman, J. W. Fell \& T. Boekhout. Amsterdam: Elsevier.

Golubev, W. I., Sampaio, J. P. \& Golubeva, E. W. (2006). Cryptococcus stepposus, a new filobasidiaceous yeast species found in the Prioksko-terrasny biosphere reserve in Russia. Mycol Res 110, 957-961.

Gurbuz, F., Ciftci, H. \& Akcil, A. (2009). Biodegradation of cyanide containing effluents by Scenedesmus obliquus. J Hazard Mater 162, 7479 .

Kjeldsen, P. (1999). Behaviour of cyanides in soil and groundwater: a review. Water Air Soil Pollut 115, 279-308.

Kurtzman, C. P. \& Robnett, C. J. (1998). Identification and phylogeny of ascomycetous yeasts from analysis of nuclear large subunit (26S) ribosomal DNA partial sequences. Antonie van Leeuwenhoek 73, 331371.

Kwon, H. K., Woo, S. H. \& Park, J. M. (2002). Degradation of tetracyanonickelate (II) by Cryptococcus humicolus MCN2. FEMS Microbiol Lett 214, 211-216.
Labuschagne, M. \& Albertyn, J. (2007). Cloning of an epoxide hydrolase-encoding gene from Rhodotorula mucilaginosa and functional expression in Yarrowia lipolytica. Yeast 24, 69-78.

Larkin, M. A., Blackshields, G., Brown, N. P., Chenna, R., McGettigan, P. A., McWilliam, H., Valentin, F., Wallace, I. M., Wilm, A. \& other authors (2007). CLUSTAL W and CLUSTAL_X version 2.0. Bioinformatics 23, 2947-2948.

Machado, M. D., Santos, M. S. F., Gouveia, C., Soares, H. M. V. M. \& Soares, E. V. (2008). Removal of heavy metals using a brewer's yeast strain of Saccharomyces cerevisiae: the flocculation as a separation process. Bioresour Technol 99, 2107-2115.

Middelhoven, W. J., Scorzetti, G. \& Fell, J. W. (2004). Systematics of the anamorphic basidiomycetous yeast genus Trichosporon Behrend with the description of five novel species: Trichosporon vadense, $T$. smithiae, T. dehoogii, T. scarabaeorum and T. gamsii. Int J Syst Evol Microbiol 54, 975-986.

Müller, W. J., Albertyn, J. \& Smit, M. S. (2007). Cycloheximide resistance in the Lipomycetaceae revisited. Can J Microbiol 53, 509513.

Nakase, T., Takematsu, A. \& Yamada, Y. (1993). Molecular approaches to the taxonomy of ballistosporous yeasts based on the analysis of the partial nucleotide sequences of $18 \mathrm{~S}$ ribosomal ribonucleic acids. J Gen Appl Microbiol 39, 107-134.

Okoli, I., Oyeka, C. A., Kwon-Chung, K. J., Theelen, B., Robert, V., Groenewald, J. Z., McFadden, D. C., Casadevall, A. \& Boekhout, T. (2007). Cryptotrichosporon anacardii gen. nov., sp. nov., a new trichosporonoid capsulate basidiomycetous yeast from Nigeria that is able to form melanin on niger seed agar. FEMS Yeast Res 7, 339-350.

Pagnocca, F. C., Legaspe, M. F., Rodrigues, A., Ruivo, C. C., Nagamoto, N. S., Bacci, M., Jr \& Forti, L. C. (2010). Yeasts isolated from a fungus-growing ant nest, including the description of Trichosporon chiarellii sp. nov., an anamorphic basidiomycetous yeast. Int J Syst Evol Microbiol 60, 1454-1459.

Pham, J. C., Huang, D. T., McGeorge, F. T. \& Rivers, E. P. (2007). Clarification of cyanide's effect on oxygen transport characteristics in a canine model. Emerg Med J 24, 152-156.

Rachinger, J., Fellner, F. A., Stieglbauer, K. \& Trenkler, J. (2002). MR changes after acute cyanide intoxication. AJNR Am J Neuroradiol 23, 1398-1401.

Rezende, R. P., Teixeira Dias, J. C., Ferraz, V. \& Linardi, V. R. (2000). Metabolism of benzonitrile by Cryptococcus sp. UFMG-Y28. J Basic Microbiol 40, 389-392.

Rustler, S. \& Stolz, A. (2007). Isolation and characterization of a nitrile hydrolysing acidotolerant black yeast-Exophiala oligosperma R1. Appl Microbiol Biotechnol 75, 899-908.

Scorzetti, G., Fell, J. W., Fonseca, Á. \& Statzell-Tallman, A. (2002). Systematics of basidiomycetous yeasts: a comparison of large subunit D1/D2 and internal transcribed spacer rDNA regions. FEMS Yeast Res 2, 495-517.

Takashima, M., Sugita, T., Shinoda, T. \& Nakase, T. (2001). Reclassification of the Cryptococcus humicola complex. Int J Syst Evol Microbiol 51, 2199-2210.

Takashima, M., Sugita, T., Toriumi, Y. \& Nakase, T. (2009). Cryptococcus tepidarius sp. nov., a thermotolerant yeast species isolated from a stream from a hot-spring area in Japan. Int J Syst Evol Microbiol 59, 181-185.

Tamura, K., Dudley, J., Nei, M. \& Kumar, S. (2007). MEGA4: molecular evolutionary genetics analysis (MEGA) software version 4.0. Mol Biol Evol 24, 1596-1599.

van der Walt, J. P. \& Yarrow, D. (1984). Methods for isolation, maintenance, classification and identification of yeasts. In The Yeasts, 
a Taxonomic Study, 3rd edn, pp. 45-101. Edited by N. J. W. Kregervan Rij. Amsterdam: Elsevier.

van Wyk, P. W. J. \& Wingfield, M. J. (1994). Ultrastructure of ascus arrangement and ascospore development in Ophiostoma seticolle. Mycologia 86, 607-614.

White, T. J., Bruns, T., Lee, S. \& Taylor, J. W. (1990). Amplification and direct sequencing of fungal ribosomal RNA genes for phylogenetics. In
PCR Protocols: A Guide to Methods and Applications, pp. 315-322. Edited by M. A. Innis, D. H. Gelfand, J. J. Sninsky \& T. J. White. San Diego, CA: Academic Press.

Yarrow, D. (1998). Methods for the isolation, maintenance and identification of yeasts. In The Yeasts, a Taxonomic Study, 4th edn, pp. 77-100. Edited by C. P. Kurtzman \& J. W. Fell. Amsterdam: Elsevier. 